\title{
Late-Holocene initiation of ice-free ecosystems in the southern Ross Sea, Antarctica
}

\author{
Steven D. Emslie ${ }^{1, *}$, Paul Arthur Berkman ${ }^{2}$, David G. Ainley ${ }^{3}$, Larry Coats ${ }^{4}$, \\ Michael Polito ${ }^{1}$ \\ ${ }^{1}$ Department of Biological Sciences, University of North Carolina, 601 S. College Road, Wilmington, North Carolina 28403, USA \\ ${ }^{2}$ Byrd Polar Research Center, Ohio State University, 1090 Carmack Road, Columbus, Ohio 43210, USA \\ ${ }^{3}$ H. T. Harvey \& Associates, 3150 Almaden Expressway, Suite 145, San Jose, California 95118, USA \\ ${ }^{4}$ Quaternary Sciences Program, Department of Geology, Northern Arizona University, Flagstaff, Arizona 86011, USA
}

\begin{abstract}
New data on marine sediments, seawater paleotemperatures, and the occupation history of Adélie penguins indicate that modern ice-free conditions in the southern Ross Sea developed only within the last 1000 yr. Here we show that penguins permanently abandoned the southern Victoria Land Coast 2000 yr ago when extensive sea-ice cover blocked access to ice-free terrain for breeding. The first colonization of Ross Island in East McMurdo Sound, where over 300000 penguins breed today, did not commence until after $1170 \mathrm{yr}$ BP when coastal areas became exposed from under the Ross Ice Shelf. Our results demonstrate that investigations of abandoned penguin colonies can provide increased resolution to Holocene paleoclimatic records and paleoceanographic conditions in Antarctica.
\end{abstract}

KEY WORDS: Antarctica $\cdot$ Adélie penguins $\cdot$ Late Holocene $\cdot$ Paleoclimate $\cdot$ Ross Sea $\cdot$ Sea ice Resale or republication not permitted without written consent of the publisher

\section{INTRODUCTION}

The Adélie penguin Pygoscelis adeliae is well known as an ice-obligate indicator species that is sensitive to environmental change (Trivelpiece et al. 1990, Smith et al. 1999, Wilson et al. 2001, Ainley 2002). Over 744000 breeding pairs, or $30 \%$ of the world population, occur on the Victoria Land Coast bordering the Ross Sea (Ainley 2002), one of the southernmost marine ecosystems on Earth. Adélie penguins require open water near their breeding colonies, with no more than 2 to $3 \mathrm{~km}$ of persistent fast ice that must be crossed on foot to reach ice-free terrain; any additional fast ice, especially lacking tide cracks associated with grounded icebergs, and colonies are very small or absent (Watanuki et al. 1997, Ainley 2002). All extant colonies on Ross Island (see Fig. 1), the largest occupied area in the southern Ross Sea (defined as the area south of the Drygalski Ice Tongue, $75^{\circ} 24^{\prime} \mathrm{S}$ ), are near open water, and penguins appear to respond quickly when new areas become accessible with a shift in seaice conditions (Wilson et al. 2001, Ainley 2002).
Current penguin distribution patterns in the southern Ross Sea result from meterologic and oceanographic conditions that produce persistent open water in East McMurdo Sound, in contrast to the multi-year fast ice that persists in West McMurdo Sound (Dayton \& Oliver 1977, Barry \& Dayton 1988). In East McMurdo Sound, wind conditions (Stonehouse 1967, Ainley 2002) and warm, southward-moving currents and ocean swells from the Ross Sea influence the annual breakup of sea ice, which in turn leads to eutrophic marine communities adjacent to penguin colonies on Ross and Beaufort Islands. In West McMurdo Sound, supercooled currents moving northward from under the McMurdo Ice Shelf promote multi-year fast ice, which leads to oligotrophic marine communities and a lack of penguin colonies along the adjacent mainland (Dayton \& Oliver 1977, Barry \& Dayton 1988).

Preserved organic remains from ornithogenic soils at abandoned penguin colonies, recognized by accumulations of juvenile penguin bones, eggshell fragments, nest pebbles, and guano on the Victoria Land Coast, provide evidence for past occupations by Adélie pen- 


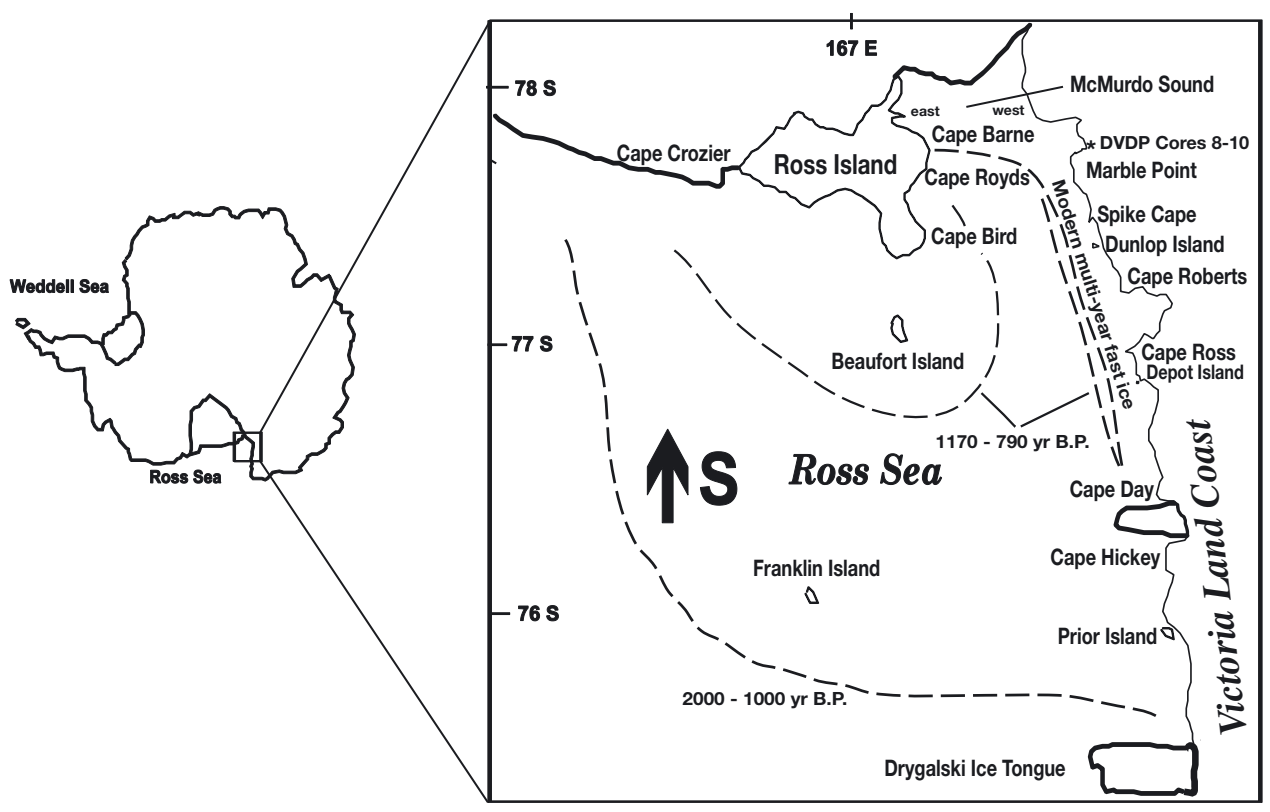

Fig. 1. Map of Antarctica showing the location of the Victoria Land Coast and Ross Island (in box) with detail of the southern Ross Sea and sampling locations (named capes and islands) discussed in the text. The location of the Dry Valley Drilling Project (DVDP) Cores 8 to 10 in a prograding delta at the mouth of Taylor Valley, west McMurdo Sound, is also provided. Bold lines indicate ice tongues and the edge of the Ross Ice Shelf; bold dashed lines represent proposed extent of permanent or multi-year fast ice at 3 time periods including modern, 1170 to $790 \mathrm{yr} \mathrm{BP}$, and 2000 to $1000 \mathrm{yr}$ BP. This last period is when permanent abandonment of the southern Victoria Land Coast occurred, and predates the first occupation of Ross Island by breeding penguins

guins (Baroni \& Orombelli 1994, Lambert et al. 2002). These data also indicate that populations north of the Drygalski Ice Tongue have remained relatively stable since the mid-Holocene (Berkman et al. 1998). This stability is due in part to the presence of the Terra Nova Bay, Passage, and Ross Sea polynyas, which developed after retreat of the West Antarctic Ice Sheet (WAIS) 7600 yr ago, based on dates from Cape Bird, Ross Island, and Franklin Island (Conway et al. 1999, but see also Andrews et al. 2002). The grounding line of WAIS had retreated to the south of Cape Ross and Ross Island, and southward along the continental coast to Hatherton Glacier $\left(80^{\circ} \mathrm{S}\right)$, by $6800 \mathrm{yr}$ ago (Licht et al. 1996, Conway et al. 1999, Hall \& Denton 1999). In contrast to the northern penguin colonies, those south of the Drygalski Ice Tongue apparently have been alternately occupied and abandoned in conjunction with shifts in ocean circulation and persistence of fast ice that influenced penguin access to ice-free terrain.

\section{MATERIALS AND METHODS}

To further investigate the occupation history of Adélie penguins in the southern Ross Sea, we sampled 13 abandoned and 3 active colonies at Marble Point and named capes and islands along the Victoria Land Coast, and at 4 capes on Ross Island, in 2001 (Fig. 1,
Table 1, Appendix 1). At each site we excavated $1 \times 1 \mathrm{~m}$ test pits in $5 \mathrm{~cm}$ levels. Excavations ceased when bedrock or the bottom of the ornithogenic soils (recognized by a change in sediment texture and color) was reached. The pit was then backfilled. All sediments were screened through 3 fine-mesh sieves (mesh sizes, from top to bottom, of $0.64,0.32$, and $0.025 \mathrm{~cm}^{2}$ ) to recover most organic remains preserved in these sites. Thirty-six samples of penguin bone, eggshell and feather fragments recovered from these excavations were submitted for radiocarbon analysis. In addition, 83 previously published radiocarbon dates on Adélie penguin remains from this region were recalibrated for comparison to our data (Table 1, Appendix 1; see below).

Due to upwelling of old carbon in Antarctica, all radiocarbon dates must be adjusted for the marinecarbon reservoir effect. There so far exists no simple or reliable method for correcting these dates, especially given the diversity of materials that often are dated (e.g. marine plants, vertebrates, and calcareous fossils). This problem has received much attention (e.g. Björck et al. 1991, Gordon \& Harkness 1992, Berkman \& Foreman 1996, Andrews et al. 1999, Domack et al. 1999a), and will not be easily resolved. Here, methods to adjust a conventional radiocarbon-derived age of penguin remains include either (1) subtracting a predetermined number of years from all dates, or (2) cor- 
recting and calibrating each date using a $\Delta \mathrm{R}$ (reservoir) value that incorporates changing differences in reservoir effects between the atmosphere and ocean through time (Stuiver et al. 1986, 1998). Method 1 provides a corrected date in radiocarbon years, while Method 2 produces a date calibrated to 'calendar years before present' (yr BP). Both methods are based on radiocarbon dates obtained on modern (before nuclear testing, pre-1950) specimens of marine organisms that yield ages from 100s to $>1000 \mathrm{yr}$ due to ingestion of old carbon during life.

Sediments and calcareous marine fossils that were deposited along the coast in West McMurdo Sound were interpreted from the Dry Valley Drilling Project (DVDP) Cores 8 to 10, which were extracted from the same hole at the base of Taylor Valley (Fig. 1). Radiocarbon dates on calcareous marine fossils recovered from DVDP Cores 8 to 10 were corrected by subtracting $1300 \mathrm{yr}$ from the conventional date, following the

Table 1. Pygoscelis adeliae. Calibrated $2 \sigma$ ranges (in calibrated yr BP) of radiocarbon dates on Adélie penguin remains from 16 sites in the southern Ross Sea, Antarctica. These ranges give maximum and minimum ages for occupation of these sites by breeding penguins based on 119 dates (see online Table 1 for data and references on each date). Multiple ranges are provided for those sites where gaps existed in the radiocarbon record, indicating a site was occupied and abandoned repeatedly in the past. Dates considered to be anomalous are not included in this table. Complete dataset published as Appendix 1, MEPS Electronic Supplement www.int-res.com/journals/suppl/emslie_appendix.pdf

\begin{tabular}{|lrr|}
\hline Site & $2 \sigma$ calibrated range (yr BP) \\
& Max. & Min. \\
\hline Beaufort Island & 328 & 0 \\
Cape Barne & 1170 & 0 \\
Cape Royds & 947 & 0 \\
Clear Lake & 878 & 492 \\
Cape Bird & 889 & 0 \\
& 4487 & 2299 \\
Cape Crozier & 617 & 0 \\
Peninsula by Depot Island & 4080 & 2059 \\
Cape Roberts & 3441 & 2694 \\
Spike Cape & 5615 & 5071 \\
Cape Ross & 4502 & 2870 \\
Dunlop Island & 6187 & 2310 \\
Franklin Island & 705 & 468 \\
& 2293 & 1813 \\
& 4960 & 4601 \\
Marble Point & 3861 & 1865 \\
Prior Island & 1351 & 515 \\
& 4618 & 3607 \\
Cape Day & 5585 & 5276 \\
Cape Hickey & 3676 & 3026 \\
& 3816 & 2291 \\
& 7434 & 7171 \\
& 15305 & 9544 \\
\hline
\end{tabular}

method of Berkman \& Forman (1996). Calcitic Antarctic scallop Adamussium colbecki fossils were further selected for stable oxygen-isotope analyses (Klein et al. 1996) because they represent a comparable paleoecological and geochemical framework to interpret ambient oceanographic conditions through time. Estimated seawater paleotemperatures, based on the $\delta^{18} \mathrm{O}$ values $( \pm 0.1 \%)$, were derived according to the equations of Craig (1965).

Unless otherwise stated, all radiocarbon dates listed herein from ice cores, debris bands, marine sediments, and calcareous fossils from the published literature (as referenced) are corrected to radiocarbon yr BP (for details on how these dates were corrected, see referenced literature). We assume these corrected dates roughly correspond to our calibrated ages for the penguin remains presented below. We do not consider our correlations between corrected dates versus calibrated dates to be a problem, as discrepancies between them are minimal for material dating to the mid- to late Holocene (Stuiver et al. 1998).

\section{RESULTS}

The 119 radiocarbon dates on penguin remains indicate that Adélie penguins first occupied the southern Ross Sea beginning at 6000 to $5000 \mathrm{yr} \mathrm{BP}$, though dates from Cape Hickey suggest that an early occupation may have occurred during the late Pleistocene from approximately 10000 to $15000 \mathrm{yr}$ BP (Table 1). Occupations during the mid-Holocene occurred only along the continental margin, following the retreat of the WAIS (Licht et al. 1996, Conway et al. 1999, Domack et al. 1999b, Hall \& Denton 1999). This initial influx of penguins occurred gradually along the Victoria Land Coast with Dunlop Island occupied first (Fig. 1). By 4000 to 3000 yr BP, during a warming period known as the 'penguin optimum' (Baroni \& Orombelli 1994), the occupation extended southward to Marble Point and lasted until 2288 to 1865 yr BP ( $2 \sigma$ calibrated range), when all sites were permanently abandoned on this southern coast. One date from Franklin Island (2293 to $1813 \mathrm{yr} \mathrm{BP})$ also extends to this latest age of abandonment (Table 1).

The permanent abandonment of the southern Victoria Land Coast was followed by the first known colonization of Ross Island at 1170 to $790 \mathrm{yr} \mathrm{BP}$, when Cape Barne was occupied by an estimated 3000 to 4000 breeding pairs. This estimate is based on the size of the abandoned area compared to modern Adélie penguin colonies (Fig. 1). Subsequently, Cape Royds, $3 \mathrm{~km}$ north of Cape Barne, was occupied at 947 to $653 \mathrm{yr}$ BP. A slightly younger buried soil at Cape Bird (797 to $530 \mathrm{yr}$ BP), containing hundreds of feather but no 
eggshell fragments, may have formed while this area was used as a molting site rather than a breeding colony. However, by approximately 600 to 500 yr BP, the colonies at Cape Bird and Cape Crozier had formed and are composed today of over 300000 breeding birds ( $8 \%$ of world population), with the latter colony being the fifth largest Adélie penguin colony in Antarctica (Woehler 1993, Ainley 2002). Two dates from Prior Island, ranging from 1351 to $815 \mathrm{yr} \mathrm{BP}$, indicate that more northern colonies were also ice-free in the early stages of this most recent colonization event (Table 1).

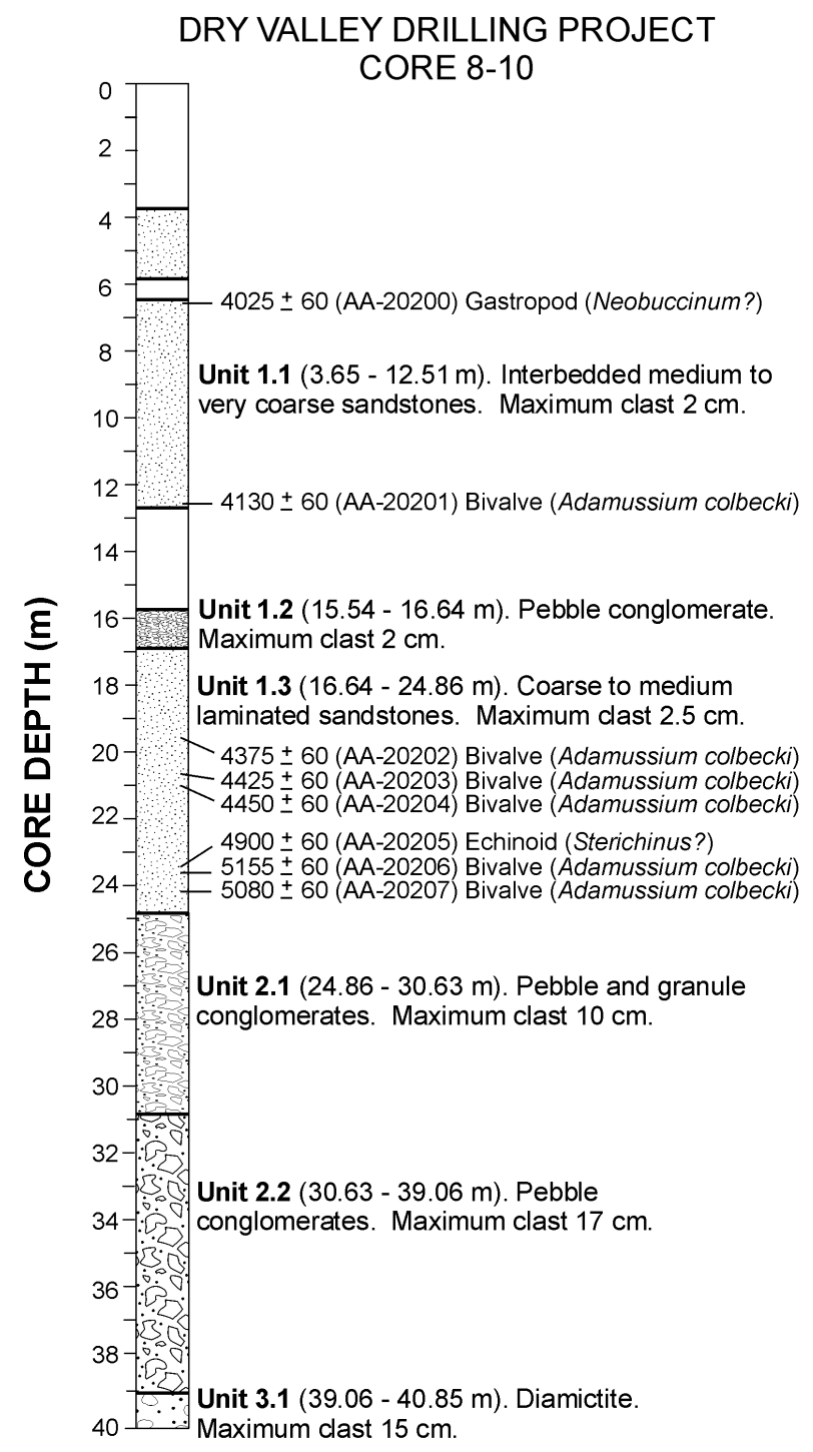

Fig. 2. Sediment profile (depths in $\mathrm{m}$ ) from the Dry Valley Drilling Project (DVDP) Cores 8 to 10 (see Fig. 1), with uncorrected radiocarbon ages for calcareous marine fossils. Laboratory numbers (AA) for each date from the University of Arizona Radiocarbon Lab. Sedimentary deposits were characterized by McKelvey (1981). Modified from Berkman \& Tipton-Everett (2001)

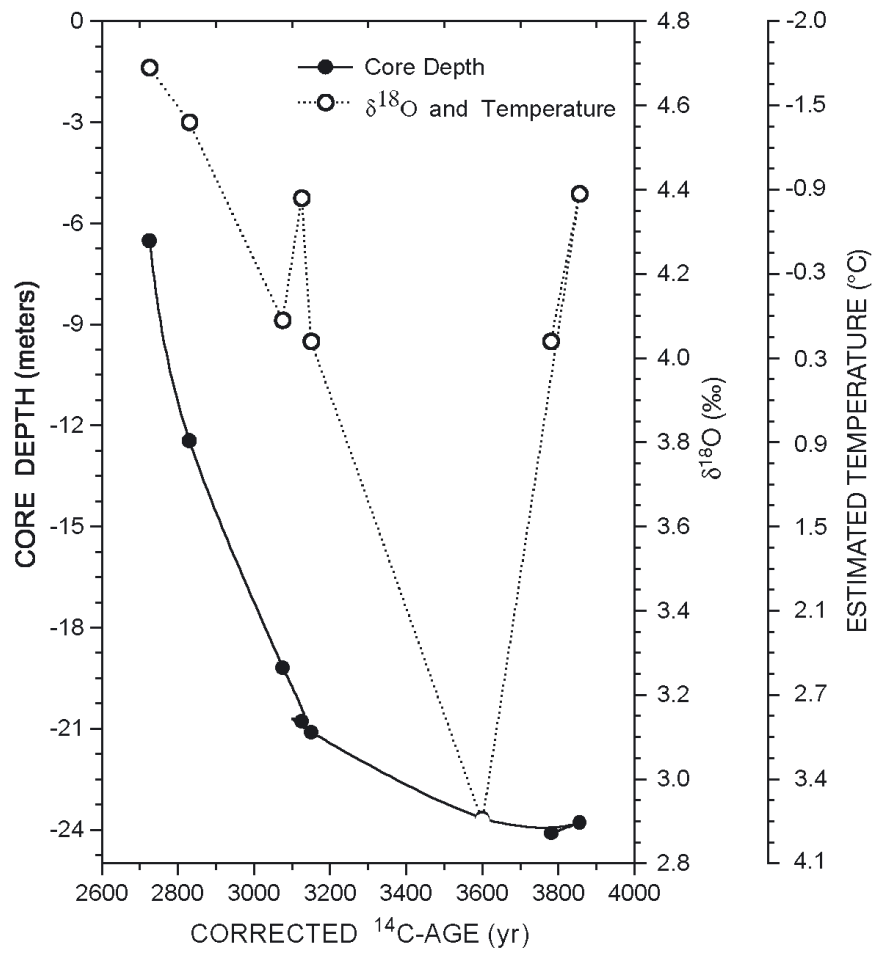

Fig. 3. Radiocarbon ages of Antarctic scallop Adamussium colbecki shell fragments, at various depths from DVDP Cores 8 to 10 (Figs. 1 \& 2), which were corrected in relation to the 1300 yr radiocarbon reservoir age of the Southern Ocean (Berkman \& Forman 1996). Corresponding oxygen-isotope $\delta^{18} \mathrm{O}$ ) values and estimated seawater paleotemperatures from the Antarctic scallop fragments at the various core depths are plotted against these corrected radiocarbon ages

Holocene sediments in DVDP Cores 8 to 10 were fine-grained sands as opposed to the underlying larger clasts that were associated with the high-energy coastal environment that existed prior to the midHolocene (McKelvey 1981). Uncorrected radiocarbon dates ranged from $5155 \pm 60$ to $4025 \pm 60 \mathrm{yr} \mathrm{BP}$ at approximately 24.1 to $6.5 \mathrm{~m}$ depth, respectively (Fig. 2). Corrected radiocarbon ages of the fossil fragments indicate that sediment accumulation rates were relatively low, from 3900 to $3100 \mathrm{yr} \mathrm{BP}$, and that they increased markedly afterwards. Oxygen isotope ratios from the fossil carbonates further indicate that there was a relatively warm interval between 3900 and 3100 yr BP (Fig. 3), with a subsequent shift toward cooler temperatures, reaching modern seawater values for West McMurdo Sound at 2700 yr BP.

\section{DISCUSSION}

Supportive data for the recent development of icefree ecosystems in the southern Ross Sea exists in the 
hydrological (ice-core), geological and glaciological records of East Antarctica (Ingólfsson et al. 1998). The Dome $\mathrm{C}$ ice core, for example, indicates a warming period from 4000 to $2500 \mathrm{yr} \mathrm{BP}$, followed by a cooling period that may have caused extensive sea-ice cover to return until 1000 yr BP (Lorius et al. 1979). The Taylor Dome ice core records a climatic shift beginning $\sim 6000 \mathrm{yr}$ BP reflected in the increased and highly variable methanesulfonic acid concentrations associated with marine primary production and sea-ice coverage (Steig et al. 1998, 2000). These continental ice-cores may not reflect the same climate trends as in the Ross Sea, but debris bands on the McMurdo Ice Shelf also have indicated that southern McMurdo Sound was filled with grounded ice until $7750 \mathrm{yr}$ BP. This ice retreated and left an ice shelf at Black Island by 6600 yr BP (uncorrected radiocarbon yr; Kellogg et al. 1990). Marine sedimentary deposits of diatoms further indicate that there was regional warming from 6000 to 3000 yr BP (Cunningham et al. 1999), with high concentrations of organic carbon in the SE Ross Sea from 5000 to 3000 yr BP (Licht et al. 1998). This warming period was followed by a distinct decrease in carbon deposition, from 3 to $4 \mathrm{~g} \mathrm{~cm}^{-2} \mathrm{yr}^{-1}$ in the midHolocene, down to 1 to $2 \mathrm{~g} \mathrm{~cm}^{-2} \mathrm{yr}^{-1}$ from 2000 to $1000 \mathrm{yr}$ BP, in the SE to central Ross Sea (Jacobson 1997), a result consistent with the presence of more concentrated sea-ice and lower marine primary productivity. The carbon flux increased again to 2 to $3 \mathrm{~g}$ $\mathrm{cm}^{-2} \mathrm{yr}^{-1}$ at $\sim 1300$ to $1000 \mathrm{yr}$ BP when, apparently, icefree marine conditions returned in the southern Ross Sea. Dry Valley lake records also support a warming period, with an increase in lake levels beginning 1200 to 1000 yr BP (Lyons et al. 1998, 1999).

New radiocarbon analyses, along with stable isotope measurements from calcareous marine fossil fragments in the uppermost section of the DVDP Cores 8 to 10, further constrain the oceanographic conditions in the southern Ross Sea during the late Holocene (Figs. 2 \& 3). The warming interval at 3900 and $3100 \mathrm{yr} \mathrm{BP}$, which is reflected by the $\delta^{18} \mathrm{O}$ values of Adamussium fragments, coincides with the 'penguin optimum' previously discussed (Baroni \& Orombelli 1994). However, the subsequent cooling occurred during a period when sand accumulation was increasing in the prograding delta adjacent to the meltwater streams at the mouth of Taylor Valley (Fig. 1). The simplest explanation for increased accumulation of sands during the cooling period after $3100 \mathrm{yr}$ BP is that increased sea-ice concentrations insulated the beaches from high-energy wave erosion.

On a broader scale, marine sedimentary data from the Antarctic Peninsula also indicate a cooling period, with a re-advance of the Larsen Ice Shelf, beginning at $\sim 2500$ yr BP (Leventer et al. 1996, Domack et al. 2001).
This cooling corresponds with the Neoglacial in the northern hemisphere, a period that ended with the onset of the Medieval Warm Period at 1000 yr BP (McDermott et al. 2001) when Ross Island was first occupied by breeding penguins.

Abandonment of the entire southern Ross Sea by penguins from 2000 to $1000 \mathrm{yr} \mathrm{BP}$, from what we now know about present population dynamics, may not be unusual. For penguins in the southern Ross Sea, the most parsimonious explanation for large-scale abandonment or absence is that persistent sea ice inhibited access to colonies. The importance of this factor has been demonstrated recently (since the 2001-2002 austral summer) when Icebergs B-15A and C-16 grounded off the north side of Ross Island, thereby blocking southward moving currents which, combined with light winds, has led to increased persistence of fast ice and concentrated pack-ice through the summer in most of East McMurdo Sound (Arrigo et al. 2002, D.G.A. \& G. Ballard unpubl. data). This sea ice has hindered access of penguins to Cape Royds and Cape Bird, and severely decreased the breeding population size and reproductive success at these colonies. It appears that, if this condition persists, these large colonies may soon be abandoned.

Ongoing occupation of Adélie penguins on Ross Island after $1170 \mathrm{yr} \mathrm{BP}$, while their colonies have remained abandoned along the Victoria Land Coast, further indicates that the modern sea-ice and oceanographic conditions that contrast across McMurdo Sound (Stonehouse 1967, Barry \& Dayton 1988) have existed, at least in the late Holocene, only during the last millennium. Adélie penguin numbers have shifted considerably over millennia in response to changing climate and sea-ice conditions, and long-term climate change, as it affects sea-ice extent, probably has been the most important factor in controlling distributions of Antarctic penguins (Ainley 2002, see also Emslie 2001). Our results demonstrate that data from abandoned and extant penguin colonies can provide increased resolution to the Holocene paleoclimatic record as revealed in sediment and ice cores, and that integration of biological, geological, and hydrological data are in accord with the occupation record of penguins in the southern Ross Sea.

Acknowledgements. This project was funded by grants OPP 9909274, 0042786, and 0125608 from the National Science Foundation. We thank E. Domack and G. Ballard for discussion and comments on this research. The Antarctic Marine Geology Research Facility, Florida State University, granted access to Dry Valley cores used in this study. Raytheon Polar Services provided logistical support in Antarctica. New radiocarbon dates on penguin remains reported here were completed at the Rafter Radiocarbon Lab, New Zealand; dates on calcareous marine fossils from DVDP cores 8 to 10 were completed at the Accelerator Mass Spectrometry Laboratory, Uni- 
versity of Arizona. Oxygen isotope analyses were conducted in the Department of Geological Sciences, University of Michigan. The paper was improved with comments from 4 anonymous reviewers.

\section{LITERATURE CITED}

Ainley DG (2002) The Adélie penguin: bellwether of climate change. Columbia University Press, New York

Andrews JT, Domack EW, Cunningham WL, Leventer A, Licht KJ, Jull AJ, DeMaster DJ, Jennings AE (1999) Problems and possible solutions concerning radiocarbon dating of surface marine sediments, Ross Sea, Antarctica. Quat Res 52:206-216

Andrews JT, Shipp SS, Lowe AL, Wellner JS, Mosola AB (2002) The Antarctic Ice Sheet during the Last Glacial Maximum and its subsequent retreat history: a review. Quat Sci Rev 21:49-70

Arrigo KR, van Dijken GL, Ainley DG, Fahnestock MA, Markus T (2002) Ecological impact of a large Antarctic iceberg. Geophys Res Let 29:8-1-8-4

Baroni C, Orombelli G (1994) Abandoned penguin colonies as Holocene paleoclimatic indicators in Antarctica. Geology 22:23-26

Barry JP, Dayton PK (1988) Current patterns in McMurdo Sound, Antarctica and their relationship to local biotic communities. Polar Biol 8:367-376

Berkman PA, Forman SL (1996) Pre-bomb radiocarbon and the reservoir correction for calcareous marine species in the Southern Ocean. Geophys Res Lett 23:633-636

Berkman PA, Tipton-Everett L (2001) Latitudinal Ecosystem (LAT-ECO) responses to climate across Victoria Land, Antarctica. Report No. 20. Byrd Polar Res Center, Columbus, OH, p 1-152

Berkman PA, Andrews JT, Björck S, Colhoun EA and 13 others (1998) Circum-Antarctic coastal environmental shifts during the late Quaternary reflected by emerged marine deposits. Antarct Sci 10:345-362

Björk S, Hjort C, Ingólfsson Ó, Skog G (1991) Radiocarbon dates from the Antarctic Peninsula region-problems and potential. Quat Proc 1:55-65

Conway H, Hall BL, Denton GH, Gades AM, Waddington ED (1999) Past and future grounding-line retreat of the West Antarctic Ice Sheet. Science 286:280-283

Craig H (1965) The measurement of oxygen isotope paleotemperatures. In: Tongiorgi E (ed) Oceanographic studies and paleotemperatures. Consiglio Nazionale delle Ricerche, Laboratorio de Geologica Nucleare, Pisa, p 1-24

Cunningham WL, Leventer A, Andrews JT, Jennings AE, Licht KJ (1999) Late Pleistocene-Holocene marine conditions in the Ross Sea, Antarctica: evidence from the diatom record. Holocene 9:129-139

Dayton PK, Oliver JP (1977) Antarctic soft bottom benthos in oligotrophic and eutrophic environments. Science 197: 55-58

Dochat TM, Marchant DR, Denton GH (2000) Glacial geology of Cape Bird, Ross Island, Antarctica. Geografiska Ann 82A:237-247

Domack EW, Hall B, Hayes JM (1999a) Accurate Antarctic dating technique sought by Quaternary community. Eos 80:591-597

Domack EW, Jacobson EA, Shipp S, Anderson JB (1999b) Late Pleistocene-Holocene retreat of the West Antarctic Ice-Sheet system in the Ross Sea. Part 2. Sedimentologic and stratigraphic signature. Geol Soc Am Bull 111: $1517-1536$
Domack E, Leventer A, Gilbert R, Brachfeld S and 5 others (2001) Cruise reveals history of Holocene Larsen Ice Shelf. EOS Trans Am Geophys Union 82:13, 16-17

Emslie SD (1995) Age and taphonomy of abandoned penguin rookeries in the Antarctic Peninsula region. Polar Rec 31: 409-418

Emslie SD (2001) Radiocarbon dates from abandoned penguin colonies in the Antarctic Peninsula region. Antarct Sci 13:289-295

Gordon JE, Harkness DD (1992) Magnitude and geographic variation of the radiocarbon content in Antarctic marine life: implications for reservoir corrections in radiocarbon dating. Quat Sci Rev 11:697-708

Hall BL, Denton GH (1999) New relative sea-level curves for the southern Scott Coast, Antarctica: evidence for Holocene deglaciation of the western Ross Sea. J Quat Sci 14:641-650

Heine JC, Speir TW (1989) Ornithogenic soils of the Cape Bird Adelie penguin rookeries, Antarctica. Polar Biol 10: 89-99

Ingólfsson $\mathrm{O}$, Hjort $\mathrm{C}$, Berkman PA, Björck $\mathrm{S}$ and 7 others (1998) Antarctic glacial history since the Last Glacial Maximum: an overview of the record on land. Antarct Sci 10:326-344

Jacobson EA (1997) Ice shelf sedimentation and the Holocene climatic optimum in the Ross Sea, Antarctica. BA thesis, Hamilton College, Clinton, NY

Kellogg TB, Kellogg DE, Stuiver M (1990) Late Quaternary history of the southwestern Ross Sea: evidence from debris bands on the McMurdo Ice Shelf, Antarctica. In: Elliot D (ed) Contributions to Antarctic research. I. Am Geophys Union, Antarct Res Ser 50:25-56

Klein RT, Lohmann KC, Thayer CW (1996) Bivalve skeletons record sea-surface temperature and salinity via $\mathrm{Mg} / \mathrm{Ca}$ and ${ }^{18} \mathrm{O} /{ }^{16} \mathrm{O}$ ratios. Geology 24:415-418

Lambert DM, Ritchie PA, Millar CD, Holland B, Drummond AJ (2002) Rates of evolution in ancient DNA from Adélie penguins. Science 295:2270-2273

Leventer A, Domack EW, Ishman SE, Brachfeld S, McClennen CE, Manley P (1996) Productivity cycles of 200-300 years in the Antarctic Peninsula region: understanding linkages among the sun, atmosphere, oceans, sea ice, and biota. Geol Soc Am Bull 108:1626-1644

Licht KJ, Jennings AE, Andrews JT, Williams KM (1996) Chronology of late Wisconsin ice retreat from the western Ross Sea, Antarctica. Geology 24:223-226

Licht KJ, Cunningham WL, Andrews JT, Domack EW, Jennings AE (1998) Establishing chronologies from acidinsoluble organic ${ }^{14} \mathrm{C}$ dates on Antarctic (Ross Sea) and Arctic (North Atlantic) marine sediments. Polar Res 17: 203-216

Lorius CL, Merlivat L, Jouzel J, Pourchet MA (1979) 30, 000-yr isotope climatic record from Antarctic ice. Nature 280: $644-648$

Lyons WB, Tyler SW, Wharton RA Jr, McKnight DM, Vaughn BH (1998) A late Holocene desiccation of Lake Hoare and Lake Fryxell, McMurdo Dry Valleys, Antarctica. Antarct Sci 10:247-256

Lyons WB, Frape SK, Welch KA (1999) History of McMurdo Dry Valley lakes, from stable chlorine isotope data. Geology 27:527-530

McDermott F, Mattey DP, Hawkesworth C (2001) Centennialscale Holocene climate variability revealed by a highresolution speleothem $\delta^{18} \mathrm{O}$ record from SW Ireland. Science 294:1328-1331

McKelvey BC (1981) The lithospheric logs of DVDP cores 10 and 11, Easter Taylor Valley. In: McGinnis LD (ed) Dry 
Valley drilling project. Am Geophys Union, Antarct Res Ser 33:63-94

Smith RC, Ainley D, Baker K, Domack E and 7 others (1999) Marine ecosystem sensitivity to climate change. Bioscience 49:393-404

Speir TW, Cowling JC (1984) Ornithogenic soils of the Cape Bird Adelie penguin rookeries, Antarctica. 1. Chemical properties. Polar Biol 2:199-205

Spellerberg IF (1970) Abandoned penguin rookeries near Cape Royds, Ross Island, Antarctica and ${ }^{14} \mathrm{C}$ dating of penguin remains. NZ J Sci 13:380-385

Steig EJ, Hart CP, White JWC, Cunningham WL, Davis MD, Saltzman ES (1998) Changes in climate, ocean and icesheet conditions in the Ross embayment, Antarctica, at 6 ka. Ann Glaciol 27:305-310

Steig EJ, Morse DL, Waddington ED, Stuiver M, Grootes PM, Mayewski PA, Twickler MS, Whitlow SI (2000) Wisconsinan and Holocene climate history from an ice core at Taylor Dome, western Ross Embayment, Antarctica. Geografiska Ann 82A:213-235

Stonehouse B (1967) Occurrence and effects of open water in McMurdo Sound, Antarctica, during winter and early spring. Polar Rec 13:775-778

Stonehouse B (1970) Recent climatic change in Antarctica suggested from ${ }^{14} \mathrm{C}$ dating of penguin remains. Palaeogeol Palaeoclimatol Palaeoecol 7:341-343

Editorial responsibility: Otto Kinne (Editor),

Oldendorf/Luhe, Germany
Stuiver M, Reimer PJ (1993) Extended ${ }^{14} \mathrm{C}$ data base and revised CALIB $3.0{ }^{14} \mathrm{C}$ age calibration program. Radiocarbon 35:215-230

Stuiver M, Pearson GW, Braziunas T (1986) Radiocarbon age calibration of marine samples back to 9000 cal. yr BP. Radiocarbon 28:980-1021

Stuiver M, Reimer PJ, Bard E, Beck JW and 6 others (1998) INTCAL98 radiocarbon age calibration, 24,000-0 cal BP. Radiocarbon 40:1041-1083

Trivelpiece WZ, Trivelpiece SG, Geupel GR, Kjelmyr J, Volkman NJ (1990) Adélie and chinstrap penguins: their potential as monitors of the southern ocean marine ecosystem. In: Kerry KR, Hempel G (eds) Antarctic ecosystems. Springer-Verlag, Berlin, p 191-202

Watanuki Y, Kato A, Naito Y, Robertson G, Robinson S (1997) Diving and foraging behaviour of Adélie penguins in areas with and without fast sea-ice. Polar Biol 17: 296-304

Wilson PR, Ainley DG, Nur N, Jacobs SS, Barton KJ, Ballard G, Comiso JC (2001) Adélie penguin population change in the pacific sector of Antarctica: relation to sea-ice extent and the Antarctic Circumpolar Current. Mar Ecol Prog Ser 213:301-309

Woehler E (1993) The distribution and abundance of Antarctic and subantarctic penguins. SCAR Bird Biology Subcommittee, Cambridge

Submitted: February 10, 2003; Accepted: June 13, 2003 Proofs received from author(s): September 25, 2003 